\title{
PENINGKATAN HASIL BELAJAR IPS MATERI AKTIVITAS EKONOMI MELALUI MODEL MAKE A MATCH DI KELAS IV SDN II ARYOJEDING KABUPATEN TULUNGAGUNG
}

\author{
Farraz Putri Febriani, Suminah \\ PP3 Jalan Ir. Soekarno No. 1 Blitar 66115, KSDP, FIP Universitas Negeri Malang \\ e-mail:febriani.farraz@yahoo.com
}

\begin{abstract}
Abstrak: Penerapan model pembelajaran Make a Match adalah untuk memecahkan permasalahan yang terdapat pada mata pelajaran IPS di kelas IV SDN II Aryojeding Kabupaten Tulungagung. Permasalahannya adalah sebagaian besar dari siswa kelas IV adalah hasil belajar yang disebabkan oleh guru tidak menggunakan media dalam pembelajaran, kurang memberikan motivasi dan tidak menggunakan model pembelajaran yang sesuai. Penerapan model Make a Match setelah di lakukan penelitian sebanyak 2 siklus masingmasing terdiri dari 2 pertemuan dengan 4 tahapan yang meliputi perencanaan, pelaksanaan, observasi, dan refleksi. Hasil penelitian menunjukkan ketuntasan belajar pada siklus I sebesar 36\% dan pada siklus II meningkat sebesar $86 \%$, sehingga berhasil dapat meningkatkan aktifitas guru, aktifitas siswa serta hasil belajar. Berdasarkan hasil penelitian tersebut, dapat disimpulkan bahwa penerapan model pembelajaran Make a Match dapat meningkatkan aktivitas dan hasil belajar siswa kelas IV SDN II Aryojeding Kabupaten Tulungagung.
\end{abstract}

Kata Kunci: make a match, hasil belajar, IPS

IPS merupakan mata pelajaran yang memuat berbagai konsep dasar ilmu sosial, masalah sosial, serta membahas mengenai hubungan manusia dengan lingkungannya. IPS mengkaji seperangkat peristiwa, fakta, konsep, dan generalisasi yang berkaitan dengan isu sosial (Mulyasa, 2010:125). Mata pelajaran IPS di Sekolah Dasar, diharapkan siswa dapat memiliki pengetahuan dan wawasan tentang konsep-konsep dasar ilmu sosial, memiliki kepekaan dan kesadaran terhadap masalah sosial di lingkungannya, serta memiliki keterampilan mengkaji dan memecahkan masalah- masalah sosial tersebut.

Kenyataan di lapangan, pembelajaran IPS di Sekolah Dasar masih menghadapi banyak kendala. Hasil observasi yang dilakukan peneliti di SDN II Aryojeding Kabupaten Tulungagung terdapat permasalahan baik dari guru maupun siswa. Permasalahan dari guru yaitu guru kurang memberikan motivasi siswa dan kurang variasi menggunakan metode ceramah. Sedangkan dari siswa permasalahannya meliputi rendahnya kemampuan siswa dalam hal mengingat materi. Dampaknya adalah hasil belajar siswa yang masih rendah dibawah KKM, yang telah ditentukan oleh sekolah yaitu 70, dari 14 siswa sebanyak 10 siswa belum tuntas dan hanya 4 siswa yang tuntas belajar. Solusi pemecahan masalah tersebut diperlukan pembelajaran yang dapat memotivasi siswa untuk lebih aktif, kreatif, inovatif, dan menyenangkan guna meningkatkan hasil belajar siswa diantaranya adalah dengan menerapkan model pembelajaran Make a Match untuk siswa.

Model pembelajaran Make a Match menurut Rusman (2012: 233) salah satu 
jenis dari metode pembelajaran kooperatif. Salah satu keunggulan model Make a Match adalah siswa mencari pasangan sambil belajar mengenai konsep atau topik, dalam suasana yang menyenangkan. Make a Match merupakan suatu model pembelajaran yang menciptakan suasana kelas yang menyenangkan karena dengan model ini siswa dapat belajar sekaligus bermain. Hal ini diperkuat dengan pendapat Shoimin (2014: 98) yang mengatakan bahwa karakteristik model pembelajaran Make a Match memiliki hubungan yang erat dengan karakteristik siswa yang gemar bermain.

\section{METODE}

Penelitian ini menggunakan pendekatan penelitian kualitatif. Sedangkan jenis penelitian adalah Penelitian Tindakan Kelas (PTK). Penelitian tindakan kelas merupakan suatu pencermatan terhadap kegiatan belajar berupa sebuah tindakan, yang sengaja dimunculkan dan terjadi dalam sebuah kelas secara bersama (Arikunto dkk, 2010:3). Tujuannya untuk memperbaiki proses pembelajaran. Rancangan penelitian menggunakan model Kemmis dan M.C Taggart yaitu pra tindakan, siklus I dan siklus II. Setiap siklus meliputi rencana (planning), tindakan (action), pengamatan (observation), dan refleksi (reflection). Langkah pada siklus berikutnya adalah perencanaan yang sudah direvisi, tindakan, pengamatan, dan refleksi. Sebelum masuk siklus I, dilakukan tindakan pendahuluan yang berupa identifikasi masalah. Dalam penelitian ini, peneliti berperan sebagai perancang, pelaksana, pengumpul data sekaligus sebagai observer, penganalisis data dan penyimpulan, serta pembuat laporan penelitian.

Pengambilan data penelitian dilakukan di SDN II Aryojeding Kabupaten Tulungagung semester II tahun ajaran 2015/2016. Subjek penelitian ini adalah semua siswa kelas IV SDN II Aryojeding Kabupaten Tulungagung dengan siswa yang berjumlah 14 siswa yang terdiri dari 5 laki-laki dan 9 perempuan.
Data yang dibutuhkan dalam penelitian ini mengenai pelaksanaan pembelajaran yang berupa data hasil observasi terhadap aktivitas belajar siswa, observasi aktivitas guru selama pembelajaran dengan menerapkan model pembelajaran Make a Match, dan data hasil belajar siswa.

Sumber data dalam penelitian ini adalah siswa kelas IV SDN II Aryojeding, guru, dan peneliti. Dalam hal ini peneliti bertindak sebagai pelaksana tindakan sedangkan mitra peneliti (guru kelas) sebagai observer. Pengumpulan data meliputi teknik pengumpulan data dan instrumen pengumpulan data. Teknik pengumpulan data terdiri dari pedoman observasi, wawancara, dokumentasi, pedoman tes, dan catatan lapangan. Sedangkan instrumen pengumpulan data pada penelitian ini mencakup lembar observasi aktivitas guru dan siswa, lembar wawancara, dan lembar soal evaluasi.

Analisis data yang digunakan dalam penelitian ini adalah analisa data kualitatif yaitu analisis yang dilakukan saat pengumpulan data berlangsung, dan setelah pengumpulan data dalam periode tertentu. Langkah-langkah analisis tersebut terdiri dari tiga alur kegiatan yang terjadi secara bersamaan yaitu: (1) reduksi data, (2) penyajian data, dan (3) penarikan kesimpulan.

Hasil observasi pada lembar observasi aktivitas guru dan siswa kemudian dihitung berdasarkan rumus yang ditentukan. Sedangkan hasil pelaksanaan tes kemudian dikelompokkan antara siswa yang tuntas dan belum tuntas belajar. Hasil belajar siswa diperoleh dari nilai kognitif (tes akhir), nilai afektif, dan nilai psikomotor untuk selanjutnya dicari rata-ratanya. Siswa dikatakan tuntas belajar secara individu apabila nilainya di atas KKM, sedangkan yang belum tuntas apabila nilainya di bawah KKM. Penetapan skor kriteria ketuntasan minimal mata pelajaran IPS sebesar 70. Sedangkan siswa dikatakan tuntas belajar secara klasikal apabila 80\% siswa dalam satu kelas telah mencapai nilai 70 . 


\section{HASIL}

\section{Pratindakan}

Pada tahap pratindakan, diketahui guru masih menggunakan metode ceramah, tanya jawab, dan pemberian tugas. Guru tidak menggunakan model pembelajaran maupun media pembelajaran, sehingga siswa cenderung merasa bosan dan kesulitan dalam memahami materi yang disampaikan. Berdasarkan data observasi pratindakan yang telah dilaksanakan, diperoleh data bahwa pada pembelajaran pratindakan rata-rata nilai siswa kelas IV adalah 53. Siswa yang tuntas belajar sebanyak 4 siswa sedangkan 10 siswa diantaranya belum tuntas belajar. Apabila dipersentasikan siswa yang tuntas belajar adalah 29\%, dan yang belum tuntas $71 \%$ dari jumlah siswa keseluruhan. Jadi hasil tes tulis pembelajaran pada pratindakan termasuk dalam kategori sangat kurang. Sebagai upaya meningkatkan hasil belajar, maka dilakukan perbaikan dalam pembelajaran dengan menggunakan model Make a Match pada siklus I.

\section{Siklus I}

\section{Perencanaan}

Perencanaan siklus I dilakukan berdasarkan hasil refleksi dari tahap pratindakan. Kegiatan perencanaan yang dilakukan meliputi (1) menyusun rencana pelaksanaan pembelajaran (RPP) dengan menggunakan model pembelajaran Make a Match, (2) mempersiapkan media pembelajaran dan sumber belajar yang digunakan dalam pembelajaran, (3) membuat kartu soal dan kartu jawaban yang digunakan dalam penerapan model Make a Match, (4) membuat Lembar Kerja Kelompok (LKK), (5) membuat tes akhir berupa soal evaluasi kepada siswa, (6) menyiapkan instrumen penilaian aktivitas siswa dan guru, catatan lapangan, serta lembar penilaian kognitif, afektif, dan psikomotor, (7) melakukan dokumentasi berupa foto.

\section{Pelaksanaan}

Pelaksanaan pembelajaran siklus I pertemuan 1 dilaksanakan pada hari Jumat tanggal 26 Februari 2016 dan pertemuan 2 dilaksanakan pada hari Senin tanggal 29 Februari 2016. Guru telah melaksanakan pembelajaran sesuai dengan RPP yang telah disusun berdasarkan model Make a Match.

\section{Observasi}

Observasi dilaksanakan pada saat pembelajaran berlangsung. Selama kegiatan berlangsung observer mengamati aktivitas guru dan siswa selama pembelajaran berlangsung, serta hasil belajar siswa yang diperoleh peneliti.

\section{Hasil Observasi Aktivitas Guru \\ Tabel 1 Rekapitulasi Aktivitas Guru pada Pembelajaran Siklus I

\begin{tabular}{lcll}
\hline No & $\begin{array}{c}\text { Pelaksanaan } \\
\text { Siklus I }\end{array}$ & $\begin{array}{c}\text { Persentase } \\
\text { Ketuntasan } \\
\text { Aktivitas } \\
\text { Guru }\end{array}$ & Predikat \\
\hline 1. & Pertemuan 1 & $83 \%$ & Baik \\
2. & Pertemuan 2 & $89 \%$ & Sangat Baik \\
\hline Rata-rata & $\mathbf{8 6 \%}$ & Sangat Baik \\
\hline
\end{tabular}

Tabel 1 tersebut menjelaskan bahwa siklus I pertemuan 1 ketuntasan aktivitas guru sebesar $83 \%$ dari 18 aspek mulai dari kegiatan awal hingga akhir dengan predikat baik. Pertemuan 2 persentase ketuntasan aktivitas guru sebesar $89 \%$ dengan predikat sangat baik. Rata-rata ketuntasan aktivitas guru dalam pertemuan 1 dan pertemuan 2 sebesar $86 \%$ dengan kriteria sangat baik.

\section{Hasil Observasi Aktivitas Siswa}

Tabel 2 Rekapitulasi Aktivitas Siswa pada Siklus I

\begin{tabular}{lccc}
\hline No & $\begin{array}{c}\text { Pelaksanaan } \\
\text { Siklus I }\end{array}$ & $\begin{array}{c}\text { Persentase } \\
\text { Ketuntasan } \\
\text { Aktivitas Siswa }\end{array}$ & Predikat \\
\hline 1. & Pertemuan 1 & $59 \%$ & Kurang \\
2. & Pertemuan 2 & $66 \%$ & Cukup \\
\hline Rata-rata & $\mathbf{6 2 , 5 \%}$ & Cukup \\
\hline
\end{tabular}


Tabel 2 menunjukkan aktivitas siswa pada pertemuan 1 masih rendah. Hal ini terbukti dari 6 aspek yang diamati, ketuntasan aktivitas siswa hanya sebesar 59\% dengan predikat kurang. Pertemuan 2 terjadi peningkatan ketuntasan aktivitas siswa menjadi $66 \%$ dengan predikat cukup. Hal ini berarti terjadi peningkatan sebesar 7\%. Rata-rata aktivitas siswa sebesar $62,5 \%$ dengan predikat cukup.

\section{Hasil Belajar Siswa}

Nilai hasil belajar siswa diperoleh dari tes akhir (kognitif), nilai afektif, dan nilai psikomotor siswa untuk selanjutnya dicari rata-ratanya. Data nilai hasil belajar siswa pada siklus I pertemuan 1 dan pertemuan 2 tertuang dalam tabel sebagai berikut.

Tabel 3 tersebut menunjukkan rekapitulasi hasil belajar siswa pada siklus I dengan ratarata sebesar $63,2 \%$ dengan predikat cukup. Dari 14 siswa, 5 siswa dinyatakan sudah tuntas sedangkan 9 siswa dinyatakan belum tuntas. Ketuntasan belajar secara klasikal pada siklus I masih rendah yaitu hanya 36\% dengan predikat sangat kurang.

\section{Refleksi}

Berdasarkan hasil observasi dan analisis data pada siklus I, diperoleh hasil yaitu masih ada kekurangan pada beberapa aspek yang terlihat dalam data observasi aktivitas guru pada pertemuan 1 dan pertemuan 2 selama guru mengajar. Oleh sebab itu perlu diperbaiki pada siklus berikutnya. Aktivitas siswa selama kegiatan pembelajaran masih belum memenuhi kriteria yang diinginkan. Hal ini dikarenakan sebagian besar siswa belum mengenal dan memahami dengan benar langkah-langkah dalam penerapan model pembelajaran Make a Match terutama pada pertemuan 1. Hal ini menyebabkan beberapa siswa pasif saat kegiatan pembelajaran berlangsung. Hasil belajar siswa pada siklus I diketahui terjadi peningkatan dari pertemuan 1 ke pertemuan 2 walaupun belum signifikan dan belum mencapai ketuntasan belajar. Nilai akhir siswa pada siklus I diketahui masih belum mencapai hasil yang diinginkan. Oleh sebab itu diperlukan perbaikan hasil belajar siswa yang dilakukan pada siklus berikutnya.

\section{Siklus II \\ Perencanaan}

Perencanaan siklus II disusun berdasarkan refleksi dari tindakan siklus I. Sama seperti siklus I, pada tahap perencanaan peneliti menyusun Rencana Pelaksanaan Pembelajaran (RPP) siklus II yang terdiri dari 2 kali pertemuan dengan alokasi waktu 3x35 menit. Peneliti juga mempersiapkan media pembelajaran serta instrumen yang meliputi lembar observasi guru dan siswa, soal evaluasi, dan lembar penilaian. Pada tahap ini, peneliti harus memperbaiki beberapa aspek yang terlewatkan pada siklus berikutnya.

\section{Pelaksanaan}

Pelaksanaan pembelajaran siklus II pertemuan 1 dilaksanakan pada hari Jumat tanggal 04 Maret 2016 dan pertemuan 2 dilaksanakan pada hari Senin tanggal 07 Maret 2016. Guru telah melaksanakan pembelajaran sesuai dengan RPP yang telah disusun berdasarkan model Make a Match.

\section{Observasi}

Observasi dilaksanakan pada saat pembelajaran berlangsung. Selama kegiatan berlang-

Tabel 3 Rekapitulasi Hasil Belajar Siswa pada Siklus I

\begin{tabular}{lcccccc}
\hline \multirow{2}{*}{ Siklus I } & \multicolumn{2}{c}{ Nilai Akhir } & Rata-rata & \multicolumn{2}{c|}{ Ketuntasan Belajar } \\
\cline { 2 - 3 } & Pert. 1 & Pert. 2 & & Siklus I & T & BT \\
\hline Jumlah & 814 & 947 & 885 & 5 & 9 \\
Rata-rata & 58,1 & 67,6 & 63,2 & & \\
Persentase & $58,1 \%$ & $67,6 \%$ & $63,2 \%$ & $36 \%$ & $64 \%$ \\
Predikat & Kurang & Cukup & Cukup & Sangat Kurang & \\
\hline
\end{tabular}


sung observer mengamati aktivitas guru dan siswa selama pembelajaran berlangsung, serta hasil belajar siswa yang diperoleh peneliti.

\section{Hasil Observasi Aktivitas Guru}

\begin{tabular}{|c|c|c|c|}
\hline No & $\begin{array}{l}\text { Pelaksanaan } \\
\text { Siklus II }\end{array}$ & $\begin{array}{c}\text { Persentase } \\
\text { Ketuntasan } \\
\text { Aktivitas Guru }\end{array}$ & Predikat \\
\hline 1. & Pertemuan 1 & $94 \%$ & $\begin{array}{l}\text { Sangat } \\
\text { Baik }\end{array}$ \\
\hline 2. & Pertemuan 2 & $100 \%$ & $\begin{array}{c}\text { Sangat } \\
\text { Baik }\end{array}$ \\
\hline \multicolumn{2}{|c|}{ Rata-rata } & $97 \%$ & $\begin{array}{c}\text { Sangat } \\
\text { Baik }\end{array}$ \\
\hline
\end{tabular}

Tabel 4 tersebut menunjukkan ketuntasan aktivitas guru pada pertemuan 1 sebesar 94\% dari 18 aspek dengan predikat sangat baik. Pertemuan 2, ketuntasan aktivitas guru meningkat sebesar $100 \%$ dengan predikat sangat baik. Berdasarkan kedua siklus diketahui terjadi peningkatan aktivitas guru pada proses pembelajaran. Hal ini terbukti dengan adanya peningkatan rata-rata siklus I sebesar $86 \%$ menjadi $97 \%$ pada siklus II dengan predikat sangat baik.

\section{Hasil Observasi Aktivitas Siswa}

Tabel 5 Rekapitulasi Aktivitas Siswa pada Siklus II

\begin{tabular}{llll}
\hline No & $\begin{array}{c}\text { Pelaksanaan } \\
\text { Siklus II }\end{array}$ & $\begin{array}{c}\text { Persentase } \\
\text { Ketuntasan } \\
\text { Aktivitas Siswa }\end{array}$ & Predikat \\
\hline 1. & Pertemuan 1 & $72 \%$ & Cukup \\
2. & Pertemuan 2 & $84 \%$ & Baik \\
\hline Rata-rata & $\mathbf{7 8 \%}$ & Baik \\
\hline
\end{tabular}

Tabel 5 tersebut menunjukkan ketuntasan aktivitas siswa pada pertemuan 1 sebesar $72 \%$ dari 6 aspek dengan predikat cukup. Ketuntasan aktivitas siswa pada pertemuan 2 sebesar 84\% dengan predikat baik. Berdasarkan siklus I dan siklus II, diketahui terjadi peningkatan rata-rata aktivitas belajar siswa dengan rata-rata siklus I sebesar $62,5 \%$, menjadi $78 \%$ pada siklus II dengan predikat baik.

\section{Hasil Belajar Siswa}

Data nilai hasil belajar siswa pada siklus II pertemuan 1 dan pertemuan 2 tertuang dalam tabel sebagai berikut.

Tabel 6 tersebut menunjukkan rekapitulasi hasil belajar siswa pada siklus II dengan ratarata sebesar 79,3\% dengan predikat baik. Dari 14 siswa, 12 siswa dinyatakan sudah tuntas dan hanya ada 2 siswa yang belum tuntas. Ketuntasan belajar secara klasikal pada siklus II meningkat secara signifikan yaitu sebesar $86 \%$ dengan predikat sangat baik.

\section{Refleksi}

Berdasarkan hasil observasi dan analisis data pada siklus II, dapat disimpulkan bahwa guru dalam melaksanakan pembelajaran sudah sesuai dengan langkah-langkah model pembelajaran dan aspek-aspek dalam lembar observasi guru. Terjadi peningkatan aktivitas belajar siswa pada siklus II sehingga telah memenuhi kriteria yang diharapkan. Siswa sudah mengenal dan memahami langkah-langkah dalam penerapan model pembelajaran Make a Match, sehingga kegiatan pembelajaran berjalan dengan lancar dan siswa terlibat aktif dalam pembelajaran. Terjadi peningkatan hasil belajar siswa dari siklus I sampai siklus II serta mencapai ketuntasan belajar yang diinginkan. Terjadi peningkatan nilai akhir siswa dari siklus I ke siklus II secara signifikan. Persentase ketuntasan siswa baik secara individu maupun klasikal sudah cukup baik dan mencapai ketuntasan yang diinginkan sehingga tidak perlu diadakan siklus III.

\section{Temuan Penelitian \\ Siklus I}

Penerapan model pembelajaran Make a Match di kelas IV pada mata pelajaran IPS belum berjalan dengan baik. Hal ini dikarenakan model pembelajaran Make a Match belum pernah diterapkan sebelumnya. Oleh sebab itu, siswa belum memahami 
Tabel 6 Rekapitulasi Hasil Belajar Siswa pada Siklus II

\begin{tabular}{|c|c|c|c|c|c|}
\hline \multirow[t]{2}{*}{ Siklus II } & \multicolumn{2}{|c|}{ Nilai Akhir } & \multirow{2}{*}{$\begin{array}{c}\text { Rata-rata } \\
\text { Siklus II }\end{array}$} & \multicolumn{2}{|c|}{ Ketuntasan Belajar } \\
\hline & Pert. 1 & Pert. 2 & & $\mathbf{T}$ & BT \\
\hline Jumlah & 1029 & 1183 & 1110 & 12 & 2 \\
\hline Rata-rata & 73,5 & 84,5 & 79,3 & & \\
\hline Persentase & $73,5 \%$ & $84,5 \%$ & $79,3 \%$ & $86 \%$ & $14 \%$ \\
\hline Predikat & Cukup & Baik & Baik & Sangat Baik & \\
\hline
\end{tabular}

betul dan masih merasa kesulitan dalam menerapkan model pembelajaran ini sehingga hasil belajar siswa masih belum mencapai target yang diharapkan.

\section{Siklus II}

Penerapan model pembelajaran Make a Match di kelas IV pada siklus II sudah berjalan dengan baik. Hal ini dikarenakan siswa telah memahami langkah-langkah model pembelajaran Make a Match sehingga kegiatan pembelajaran berjalan dengan lancar. Siswa terlihat aktif dalam mengikuti pembelajaran dan percaya diri dalam mengungkapkan pendapatnya di depan kelas, sehingga hasil belajar siswa mengalami peningkatan dari siklus sebelumnya.

\section{PEMBAHASAN}

Penerapan Model Pembelajaran Make a Match dalam Pembelajaran IPS pada Materi Aktivitas Ekonomi yang Berkaitan dengan Sumber Daya Alam dan Potensi Lain Daerah

Penerapan model pembelajaran Make a Match seperti yang dipaparkan (Rusman, 2012:223) di kelas IV pada mata pelajaran IPS, secara keseluruhan sudah berjalan dengan cukup baik. Dalam penerapannya, guru menggunakan Rencana Pelaksanaan Pembelajaran (RPP) yang disesuaikan dengan langkahlangkah yang ada dalam model pembelajaran Make a Match. Dalam penerapan model Make a Match, guru menggunakan media pembelajaran berupa kartu soal dan kartu jawaban. Selain itu guru menggunakan media gambar sebagai media pendukung untuk membantu siswa mempermudah memahami materi yang disampaikan.
Awal pertemuan dalam siklus I guru masih belum bisa mengelola kelas dengan baik. Hal ini terbukti dalam lembar observasi aktivitas guru yang meliputi 18 aspek, masih ada 3 aspek yang belum muncul ketika guru melaksanakan pembelajaran. Sebagian besar siswa pun cenderung ramai sendiri dan tidak fokus pada saat guru menjelaskan materi. Selain itu, siswa juga masih belum memahami betul langkah dalam model pembelajaran Make a Match. Hal ini dikarenakan model Make a Match belum pernah diterapkan sebelumnya terutama di kelas IV, sehingga siswa masih terlihat kebingungan saat menerapkan model tersebut. Oleh sebab itu, guru diharuskan merefleksi hasil dari setiap pertemuan untuk dijadikan bahan dalam perencanaan pada pertemuan berikutnya agar terjadi peningkatan aktivitas siswa dan guru serta hasil belajar siswa.

Pelaksanaan tindakan pada siklus II, diketahui terjadi peningkatan hasil belajar dan aktivitas siswa maupun guru. Dari hasil refleksi pada siklus II, guru sudah bisa menguasai kelas dengan cukup baik. Hal ini terbukti pada lembar observasi aktivitas guru, 18 aspek sudah muncul dalam pelaksanaan pembelajaran. Selain itu, siswa sudah mengenal dan memahami langkah-langkah model pembelajaran Make a Match, sehingga kegiatan pembelajaran berjalan dengan lancar dan siswa terlibat aktif dalam pembelajaran. Keaktifan siswa dalam mengikuti pembelajaran dapat dilihat pada lembar aktivitas siswa dengan 6 aspek yang diamati sudah muncul dalam pembelajaran. Selain itu, pada saat guru melakukan tanya jawab banyak siswa aktif menjawab pertanyaan guru. Siswa juga terlihat antusias dalam penerapan model Make a Match dan 
mulai berani mengemukakan pendapatnya pada saat presentasi di depan kelas.

Berdasarkan data yang telah diperoleh, diketahui bahwa aktivitas guru dan aktivitas siswa pada penerapan model pembelajaran Make a Match mengalami peningkatan di setiap siklusnya. Hal ini sesuai dengan teori dari (Rusman, 2012:223) mengatakan bahwa model Make a Match siswa belajar secara aktif sambil menguasai konsep atau topik dalam suasana yang menyenangkan, sehingga diharapkan hasil belajar siswa lebih meningkat. Teori ini diperkuat oleh penelitian yang dilakukan oleh Ahmad Dennis Widya Pradana (2014) menyatakan bahwa setelah diterapkan model pembelajaran Make a Match, aktivitas dan hasil belajar siswa di kelas IV terjadi peningkatan.

Pelaksanaan siklus I, persentase aktivitas guru mencapai $86 \%$ sedangkan aktivitas siswa mencapai $62,5 \%$. Setelah dilakukan refleksi serta perbaikan pada siklus II, terjadi peningkatan secara signifikan pada persentase aktivitas guru yaitu sebesar 100\% dengan predikat sangat baik. Sedangkan persentase aktivitas siswa meningkat menjadi 78\% dengan predikat baik.

\section{Peningkatan Hasil Belajar IPS pada Siswa Kelas IV SDN II Aryojeding Melalui Model Make a Match}

Hasil belajar menurut Bloom (dalam Suprijono, 2009:5) mencakup kemampuan kognitif, afektif dan psikomotorik. Berdasarkan hasil observasi pada tahap pratindakan, diketahui bahwa hasil belajar siswa masih sangat rendah. Dalam tahap ini, hanya ada 4 siswa yang dinyatakan tuntas belajar atau berada di atas KKM dan 10 siswa lainnya dinyatakan belum tuntas. Nilai rata-rata kelas dalam aspek kognitif pada tahap pratindakan masih rendah yaitu hanya sebesar 53 dengan predikat sangat kurang. Selain itu, ketuntasan belajar secara klasikal masih belum mencapai hasil yang diharapkan yaitu hanya sebesar $29 \%$. Dengan nilai ketuntasan tersebut, maka pembelajaran dikatakan belum berhasil dan perlu dilakukan perbaikan pada siklus I.

Pelaksanaan tindakan yang telah dilakukan pada siklus I, diketahui terjadi peningkatan hasil belajar siswa walaupun belum secara signifikan. Hal ini terbukti pada pertemuan 1 nilai rata-rata aspek psikomotor sebesar 68,6, aspek kognitif sebesar 59,3, dan aspek afektif sebesar 46,7. Sedangkan pada pertemuan 2, nilai rata-rata aspek psikomotor sebesar 77,2 , aspek kognitif 69,4 , dan aspek afektif 56,3 . Nilai rata-rata hasil belajar mencapai 58,1 pada pertemuan 1 dan mengalami peningkatan menjadi 67,6 pada pertemuan 2 . Sedangkan nilai rata-rata kelas pada siklus I mencapai 63,2 dengan predikat cukup yang artinya terjadi peningkatan sebesar 10,1 dari tahap pratindakan. Persentase ketuntasan belajar siswa secara klasikal sebesar 36\% atau terdapat 5 siswa yang mencapai nilai diatas KKM. Peningkatan yang terjadi pada siklus I dibandingkan dengan tahap pratindakan adalah bahwa adanya perubahan gaya belajar yang semula hanya berpusat pada guru, menjadi pembelajaran yang melibatkan siswa secara aktif dan kooperatif. Namun, nilai hasil belajar siswa pada siklus I masih belum memenuhi hasil yang diharapkan. Maka dari itu, diperlukan perbaikan hasil belajar pada siklus berikutnya.

Pada pelaksanaan tindakan siklus II, diketahui terjadi peningkatan hasil belajar siswa dibandingkan dengan siklus I. Hal ini terbukti pada pertemuan 1 siklus II terjadi peningkatan pada 3 aspek yaitu aspek psikomotor sebesar 84,3, aspek kognitif sebesar 76,3, dan aspek afektif sebesar 59,3. Sedangkan pada pertemuan 2 , nilai rata-rata aspek psikomotor sebesar 89,8 , aspek kognitif 85 , dan aspek afektif 78. Nilai rata-rata hasil belajar siswa pada pertemuan 1 sebesar 73,5 dan mengalami peningkatan pada pertemuan 2 sebesar 84,5. Sedangkan nilai rata-rata kelas pada siklus II mencapai 79,3 dengan predikat baik. Dalam siklus II diketahui terjadi peningkatan persentase ketuntasan belajar siswa secara klasikal yaitu sebesar $86 \%$ dimana terdapat 12 
siswa yang dinyatakan tuntas belajar yang artinya siswa sudah mencapai ketuntasan belajar secara klasikal ( $\geq 80 \%)$. Hal ini sejalan dengan pendapat Sudjana (2011: 8) dimana keberhasilan siswa ditentukan kriterianya yakni berkisar antara $75-80 \%$. Dengan demikian, dapat diartikan bahwa model pembelajaran Make a Match dapat meningkatkan hasil belajar siswa pada mata pelajaran IPS di kelas IV SDN II Aryojeding Kabupaten Tulungagung.

\section{PENUTUP}

\section{Kesimpulan}

Pelaksanaan pembelajaran IPS dengan menerapkan model pembelajaran Make a Match di kelas IV SDN II Aryojeding Kabupaten Tulungagung sudah berjalan dengan cukup baik. Hal ini terbukti dengan meningkatnya aktivitas belajar siswa pada setiap siklusnya. Pada siklus I, aktivitas belajar siswa sebesar $62,5 \%$ dan meningkat menjadi $78 \%$ pada siklus II. Sedangkan aktivitas guru pada siklus I sebesar $86 \%$ dan meningkat menjadi $100 \%$ pada siklus II.

Penerapan model pembelajaran Make a Match pada mata pelajaran IPS dapat meningkatkan hasil belajar siswa kelas IV SDN II Aryojeding Kabupaten Tulungagung. Hal ini terbukti dengan adanya peningkatan hasil belajar siswa pada tahap pratindakan, siklus I dan siklus II. Dalam tahap pratindakan, diketahui rata-rata kelas siswa sebesar 53 dan persentase ketuntasan klasikal sebesar 29\% dengan jumlah siswa tuntas sebanyak 4 siswa dan 10 siswa lainnya tidak tuntas. Pada siklus I, nilai rata-rata kelas mencapai 63,2 dan terjadi peningkatan persentase ketuntasan klasikal yaitu sebesar 36\% dengan jumlah siswa yang tuntas sebanyak 5 siswa dan 9 siswa lain dinyatakan belum tuntas. Pada siklus II, nilai rata-rata kelas mencapai 79,3 dan terjadi pe-ningkatan persentase ketuntasan klasikal yaitu sebesar $86 \%$ dengan jumlah siswa yang tuntas sebanyak 12 siswa, dan 2 siswa lain belum tuntas.

\section{Saran}

Berdasarkan penelitian yang telah dilaksanakan dengan menerapkan model pembelajaran Make a Match, maka terdapat beberapa yang disampaikan oleh peneliti yaitu apabila guru ingin meningkatkan hasil belajar siswa, maka guru diharapkan dapat memahami langkah-langkah serta dapat menerapkan model pembelajaran Make a Match yang dapat meningkatkan minat, hasil belajar serta aktivitas siswa sehingga siswa dapat terlibat secara aktif dalam kegiatan pembelajaran. Bagi sekolah, diharapkan dapat memberikan masukan serta motivasi kepada guru untuk dapat melaksanakan pembelajaran yang inovatif dan berkualitas dengan menerapkan model-model maupun media pembelajaran agar tercipta suasana belajar yang variatif dan menyenangkan.

\section{DAFTAR RUJUKAN}

Arikunto, Suharsimi, dkk. 2010. Penelitian Tindakan Kelas. Jakarta: PT Bumi Aksara. Mulyasa. 2010. Kurikulum Tingkat Satuan Pendidikan ( Mukhlis, Ed.). Bandung: PT Remaja Rosdakarya.

Pedoman Penulisan Karya Ilmiah: Skripsi, Tesis, Disertasi, Artikel, Makalah, Tugas Akhir, Laporan Penelitian. 2010. Universitas Negeri Malang

Pradana, Ahmad Dennis. 2015. Peningkatan Hasil Belajar IPS Melalui Model Make A Match di Kelas 4 SDN Selokajang 3 Kabupaten Blitar. Skripsi tidak diterbitkan. Malang: Fakultas Ilmu Pendidikan Universitas Negeri Malang.

Rusman. 2012. Model-model pembelajaran: Mengembangkan Profesionalisme Guru. Jakarta: Rajawali Pers.

Shoimin, Aris. 2014. 68 Model Pembelajaran Inovatif dalam Kurikulum 2013. Jakarta: AR-RUZZ MEDIA.

Sudjana, Nana. 2011. Penilaian Hasil Proses Belajar Mengajar. Bandung: PT Remaja Rosdakarya.

Suprijono, Agus. 2009. Cooperative Learning: Teori dan Aplikasi Paikem. Yogyakarta: Pustaka Pelajar. 